\title{
The impact of farming without nitrogen fertiliser for ten years on pasture yield and composition, milksolids production and profitability; a research farmlet comparison.
}

\author{
C.B. GLASSEY ${ }^{1}$, C.G. ROACH ${ }^{1}$, J.M. LEE ${ }^{1}$ and D.A CLARK ${ }^{2}$ \\ ${ }^{1}$ DairyNZ, Private Bag 3221, Hamilton, 3240 \\ 22 Callard Place, Hamilton, 3216 \\ Chris.glassey@dairynz.co.nz
}

\begin{abstract}
Two experimental farmlets were established in the 2001/02 season and run continuously to 2010/11, comparing the impact of two nitrogen $(\mathrm{N})$ fertiliser systems on milksolids (MS) production, profitability and the yield and composition of ryegrass-white clover pastures. Treatments were: 1) No-N. No N fertiliser applied, stocking rate $2.56 \mathrm{cow}$ equivalents/ha (including replacements); 2) Control. Average of 181 $\mathrm{kg} \mathrm{N} / \mathrm{ha} /$ year applied as urea, stocking rate $3.06 \mathrm{cows} /$ ha (replacements grazed off farm). Annual pasture production was, on average, $2.9 \mathrm{t} \mathrm{DM} /$ ha greater on the Control farmlet compared with the No-N farmlet $(\mathrm{P}<0.001)$. Annual $\mathrm{MS} / \mathrm{ha}$ was $193 \mathrm{~kg} / \mathrm{ha}$ greater $(\mathrm{P}<0.01)$ on the Control farmlet. Despite a reduction of $1.07 \mathrm{~kg}$ MS for every $\mathrm{kg} \mathrm{N}$ not applied, profitability was very similar for both farmlets in 6 of the 9 years. Compared with No-N, the profitability of the Control farmlet improved as milk price increased above \$5.10/ $\mathrm{kg}$ MS. While the farmlets confirmed that profitable milk production systems can be achieved without $\mathrm{N}$ fertiliser applications on well-established Waikato dairy pastures, $\mathrm{N}$ fertiliser is useful for increasing profitability and milk production, particularly when the ratio between milk price and the cost of fertiliser is favourable.
\end{abstract}

Keywords: Nitrogen fertiliser, pasture yield, milksolids, operating profit.

\section{Introduction}

Regional councils across New Zealand are currently setting nutrient limits for groundwater, lakes and rivers in their catchments, as required by the New Zealand Government under the National Policy Statement on Freshwater Management (Ministry for the Environment 2011). This means that New Zealand dairy farmers must improve the environmental impact of their farming, with one of the main nutrients of concern being nitrogen $(\mathrm{N})$. Regional nutrient plans will probably require dairy farmers in selected catchments to target nitrate leaching limits per hectare per year. Depending on the catchment, soil type and rainfall, this limit could be lower than many farms are currently achieving. In this situation, farm systems and their management would have to reduce farm $\mathrm{N}$ surplus to reduce $\mathrm{N}$ loss (Beukes et al. 2012). Annual dairy farm N surplus is the $\mathrm{N}$ inputs to a farm ( $\mathrm{N}$ fertiliser, $\mathrm{N}$ fixation, imported feed), less the $\mathrm{N}$ that leaves in milk, or through animal or feed sales. $\mathrm{N}$ surplus can accumulate in the soil organic matter in some cases, or is lost from the farm as gaseous emissions or leached (mainly as nitrate) below the plant root zone into sub-surface waters and eventually enters groundwater and surface water. Management practices to reduce the risk of nitrate leaching include:

- Reducing $\mathrm{N}$ fertiliser use. This will lower the $\mathrm{N}$ concentrations in pasture and thereby reduce the concentrations of $\mathrm{N}$ in the cows' diet and urine. However, it will also reduce the annual pasture yield.

- Reducing stocking rate. Reducing annual feed grown/ha means fewer cows per ha if the aim is providing similar amounts of feed per cow, without bringing in more feed. This results in less urinary $\mathrm{N}$ being deposited on pastures or crops.

If $\mathrm{N}$ leaching limits are imposed, implementing these management practices will mean substantial changes to the farm system, and potentially impact on both milksolids (MS) production and farm profitability. Before 1990, New Zealand dairy farming was based on low $\mathrm{N}$ fertiliser applications, and mainly relied on $\mathrm{N}$ inputs from clover $\mathrm{N}$ fixation (Ledgard \& Steele 1992). Changes in the last 23 years that have created uncertainty about farming with reduced fertiliser $\mathrm{N}$ input include:

- $\mathrm{N}$ fertiliser use in New Zealand has increased seven-fold from 1991 to 2009, with $\mathrm{N}$ use on dairy farms in 2009 averaging $120 \mathrm{~kg} \mathrm{~N} / \mathrm{ha}$, (Ministry of Primary Industries 2012). More than $400 \mathrm{~kg} \mathrm{~N} / \mathrm{ha}$ is used on some farms.

- A new generation of cows. Genetic gain means an increased feed demand per cow compared with 1990 (Macdonald et al. 2008a).

- The spread of clover root weevil (Sitona lepidus), a pest of white clover throughout New Zealand (Ferguson et al. 2012). 
A return to pre-1990 farming methods with low $\mathrm{N}$ inputs would be problematic for many farmers. A new generation of dairy farmers has developed who are only familiar with managing pastures supported by $\mathrm{N}$ fertiliser use. The critical management decision rules for farming with lower $\mathrm{N}$ inputs would need to be identified to help these farmers implement low $\mathrm{N}$ input systems. For example, farmers would need to know:

- How does pasture production and management change under reduced $\mathrm{N}$ input?

- How much production risk is involved?

- What the possible consequences are for profitability?

- How effective is reducing $\mathrm{N}$ inputs in reducing $\mathrm{N}$ losses?

This paper provides a comparison of two $\mathrm{N}$ fertiliser dairy systems (zero and $181 \mathrm{~kg} \mathrm{~N} / \mathrm{ha}$ ) on two farmlets over ten years, at the same location and managed by the same decision-makers. The impacts on the yield and composition of ryegrass-white clover pastures, milk production, and profitability are described. $\mathrm{N}$ loss measurements for these farmlets will not be discussed in this paper but are reported by Ledgard et al. (2006), and Beukes et al. (2012).

\section{Material and Methods}

The two experimental farmlets were established on 1 June 2001, at DairyNZ's Scott Farm, Newstead, Hamilton. Until May 2006, these farmlets were called Treatments A and C in the Resource Efficient Dairying (RED) project (Jensen et al. 2005). For the purposes of this paper Treatment $\mathrm{A}$ is the Control farmlet and Treatment $\mathrm{C}$ is the No-N farmlet. After the RED trial these two farmlets operated alongside new farmlets established for other projects (Glassey \& Roach 2010; Beukes et al. 2012). Measurements, as described below, continued until May 2011. All data from the first year (2001/02) were removed from analysis due to an incomplete dataset.

Herds of 21 Holstein-Friesian cows were established on each farmlet in June 2001, balanced for age, expected calving date, liveweight, body condition score (BCS), breeding worth and milk somatic cell count. Annual culling allowed for five 2-year-old heifers entering each herd per year. In addition to the milking herd, the No-N farmlet had four replacement yearling heifers grazed on the farmlet each year until May 2008. From June 2008 to May 2011, the yearling replacement heifers were replaced by two cows bringing the herd size up to 23 cows. In 2009/10 and 2010/11, the size of the Control herd was also brought up to 23 cows.

The farmlet areas were 7 ha for Control and 9 ha for No-N. Therefore, stocking rates were $3.0 \mathrm{cows} / \mathrm{ha}$ for Control from 2001/02 to 2008/09 and 3.29 cows/ha during 2009/10 and 2010/11, and 2.56 cow equivalents/ ha for No-N $(1$ yearling $=0.5 \mathrm{cow})$. The stocking rates on both farmlets were designed to offer a common comparative stocking rate (CSR) of $85 \mathrm{~kg}$ liveweight $/ \mathrm{t}$ total dry matter (DM). The CSR is based on an average liveweight of $500 \mathrm{~kg} / \mathrm{cow}$ and the expectation of annual pasture growth of 17.6 and 15.0 t DM/ha for Control and No $\mathrm{N}$ farmlets respectively (Macdonald et al. 2008b).

For the Control farmlet $\mathrm{N}$ was applied as urea at 80

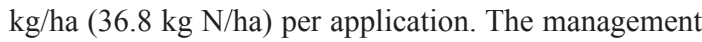
plan allowed for up to six applications over 12 months, if necessary, with up to four applications from July to December and two applications from March to May. The management team had the flexibility to reduce the number of applications in response to seasonal conditions such as drought or feed surplus.

The pastures were sown in May 2000 with $18 \mathrm{~kg} /$ ha 'Bronsyn' perennial ryegrass (Lolium perenne L.), $1.5 \mathrm{~kg} / \mathrm{ha}$ 'Grasslands Sustain' white clover (Trifolium repens L.), and $1.5 \mathrm{~kg} / \mathrm{ha}$ 'Aran' white clover. Six of the 7 ha in the Control farmlet completed all 9 years of measurement. One ha was replaced after 6 years with another 1 ha paddock sown in the same pasture species in May 2000. Six out of the 9 ha of the No-N farmlet completed all 9 years of measurement. One ha was replaced in 2003 and was measured for 8 years. Another 2 ha were replaced after 6 years. A previously replicated farmlet study at Scott Farm, (Crush et al. 2006) identified that soil type was the main source of variation between replicates. Since our study was not replicated, careful balancing for soil type variation between farmlets occurred when the farmlets were established, and this was maintained when paddocks were replaced.

Pasture mass on each paddock was assessed visually each week, and calibrated against actual mass cut from 10 quadrats (each $0.2 \mathrm{~m}^{2}$ ), four post-grazing and six pre-grazing. The quadrats were cut to ground level with an electric handpiece, washed and oven dried for 48 hours at $95^{\circ} \mathrm{C}$. Pastures were sampled monthly to the approximate grazing height for feed chemical composition by near infrared spectrometry. Botanical composition was also determined quarterly on herbage samples collected to the approximate grazing height and dissected into perennial ryegrass, white clover, weeds, other grasses and dead material on an above-residual DM basis.

\section{Milk and milk component yields; cow liveweight and body condition score}

Milk yield per cow was measured daily, with weekly samples analysed to determine crude protein and fat concentrations using a Milkoscan 133B analyser (Foss Electric, Denmark). Milksolids/ha was calculated by 
multiplying the annual MS production/cow by the stocking rate of the farmlet. Liveweight and BCS for each cow were measured fortnightly at the morning milking. A proactive animal husbandry policy was applied with in-line dispensing of bloat oil and zinc salts for prevention of bloat and facial eczema, respectively, during susceptible periods.

\section{Profitability of farmlets}

Financial evaluation of the farmlets was based on Operating Profit per ha (\$OP/ha; DairyNZ 2012). Milk income was calculated using the mean quantities for fat, protein and milk volume/ha from the farmlets, and Fonterra dairy company payments for each milk component were applied using values for $2004 / 2005$, $2009 / 2010$, and 2010/2011 dairy seasons, representing low, medium and high milk price years, respectively. Cattle income was calculated from calf sales after $25 \%$ replacements had been reared, and cull cow sales after $2 \%$ losses.

Farmlet expenses were calculated using a combination of;

Actual costs for each farmlet from records of purchased feed eaten, silage made, silage fed, nitrogen fertiliser use and grazing replacements on or off farm. Prices for 2011/2012 were used to calculate the costs. The cost of $\mathrm{N}$ applied was $\$ 1.98 / \mathrm{kg} \mathrm{N}$, or $\$ 910 / \mathrm{t}$ of urea including cartage and spreading.

Estimated costs using industry averages (DairyNZ 2013) where farm costs for individual farmlets were unable to be determined, for example, repairs and maintenance, vehicle running costs and depreciation.

Heifer grazing costs per ha for the No-N farmlet were an average over 9 years $(25 \%$ replacement rate), allowing for 6 years where $80 \%$ of the yearling replacements were grazed on the farmlet and 3 years where all replacements were grazed off.

For the financial evaluation, the information from each farmlet was used to scale up to a 100 ha farm, so that realistic estimates of labour costs could be made. Statistical analysis between years was not applied to profitability results. The same costs were applied across years, so the variation in farmlet profitability largely resulted from variation in $\mathrm{MS} / \mathrm{ha}(\mathrm{P}<0.01$, see Table 2$)$ and changes in milk price.

\section{Statistics}

All data from 2002/03 to 2010/11 (except farmlet profitability) were analysed individually as repeated measures using Mixed Models in SAS 9.3 with the mixed model including farmlet, season (i.e. winter, spring, summer, autumn) and their interaction. For all data, farming years (i.e. 1 June to 31 May) were considered as replicates.

\section{Results}

\section{Climate}

Annual rainfall from 2002/03 to 2010/11 averaged $1152 \pm 167 \mathrm{~mm}$; exactly equal to the 40 -year average. The driest year was 2007/08 (915 mm) in which rainfall during spring, summer and autumn was reduced by $24 \%, 60 \%$, and $16 \%$ compared with the 40 -year average. The wettest year was 2010/11 (1387 mm). Average minimum temperatures from $2002 / 03$ to $2010 / 11$ were $4.6,8.2,13.0$ and $8.9^{\circ} \mathrm{C}$ in winter, spring, summer and autumn, while average maximum temperatures were $14.5,18.0,23.6$ and $20.1^{\circ} \mathrm{C}$ in winter, spring, summer and autumn.

\section{Botanical composition}

On average for each year, herbage from Control pastures contained more ryegrass ( 72 vs $58 \%, \mathrm{P}<0.01$ ) and less white clover ( $7 \%$ vs $15 \%, \mathrm{P}<0.001)$ than the No-N pastures (Figure 1). No-N pastures had a greater weed content $(\mathrm{P}<0.05 ; 12$ vs $8 \%)$, but contained a similar dead matter content ( $8 \%$ on average) and other grass content ( $6 \%$ on average). Seasonal effects were evident for all botanical components, with ryegrass content greatest in winter $(\mathrm{P}<0.001)$, white clover and dead matter content greatest in summer $(\mathrm{P}<0.001)$ and weed content greatest in summer/autumn $(\mathrm{P}<0.001)$.

Table 1. Herbage nutritive value characteristics as affected by farmlet and season.

\begin{tabular}{|c|c|c|c|c|c|c|c|c|c|c|}
\hline & \multicolumn{2}{|c|}{ Farmlet } & \multicolumn{4}{|c|}{ Season } & \multirow{2}{*}{$\begin{array}{l}\text { Standard Error } \\
\text { (farmlet) }\end{array}$} & \multirow{2}{*}{$\begin{array}{l}\text { Standard Error } \\
\text { (season) }\end{array}$} & \multirow{2}{*}{$\begin{array}{l}\mathrm{P} \text { value } \\
\text { (farmlet) }\end{array}$} & \multirow{2}{*}{$\begin{array}{l}\mathrm{P} \text { value } \\
\text { (season) }\end{array}$} \\
\hline & Control & No-N & Winter & Spring & Summer & Autumn & & & & \\
\hline $\begin{array}{l}\text { Crude protein } \\
\text { (\% DM) }\end{array}$ & 20.3 & 20.1 & 19.6 & 21.4 & 18.9 & 21.0 & 0.49 & 0.48 & NS & *** \\
\hline $\begin{array}{l}\text { Neutral detergent } \\
\text { fibre (\% DM) }\end{array}$ & 45.6 & 44.6 & 41.3 & 42.9 & 48.7 & 47.5 & 0.80 & 0.91 & NS & *** \\
\hline $\begin{array}{l}\text { Organic matter } \\
\text { digestibility (\% DM) }\end{array}$ & 79.6 & 78.2 & 83.2 & 83.4 & 73.9 & 75.2 & 0.46 & 0.71 & * & *** \\
\hline $\begin{array}{l}\text { Metabolisable } \\
\text { energy (MJ/kg DM) }\end{array}$ & 11.6 & 11.5 & 12.2 & 12.2 & 10.8 & 11.0 & 0.10 & 0.11 & NS & $* \star *$ \\
\hline
\end{tabular}




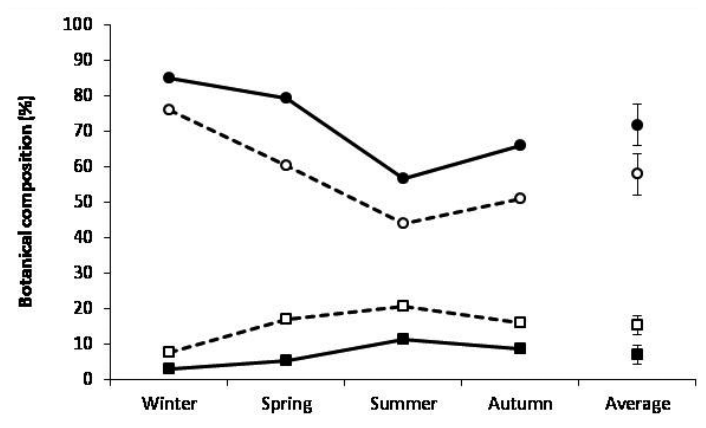

Figure 1. Percentage of ryegrass $(\bullet \circ)$ and white clover $(\bullet \square)$ in herbage harvested seasonally from Control pastures (solid lines) and those receiving no- $\mathrm{N}$ fertiliser (dotted lines). The average annual values are presented with bars indicating the 95\% confidence intervals.

\section{Nutritive characteristics}

Herbage from Control pastures was more digestible than that from No-N pastures throughout the year; other than that, all other nutritive value characteristics were similar (Table 1). All nutritive value characteristics demonstrated seasonal differences (Table 1).

\section{Pasture growth and nitrogen response}

Annual pasture production was, on average, 2.9 t DM/ ha greater on the Control farmlet compared with the No-N farmlet (18.7 vs 15.8 t DM/ha; $\mathrm{P}<0.001$; Figure 2 ). With the average $\mathrm{N}$ fertiliser use on the Control farmlet of $181 \mathrm{~kg} \mathrm{~N} / \mathrm{ha}$, this meant an apparent $\mathrm{N}$ response of $16 \mathrm{~kg} \mathrm{DM} / \mathrm{kg} \mathrm{N}$ applied. The annual feed allowances per cow were similar at $6.2 \mathrm{t} \mathrm{DM}$.

\section{Milk and milksolids production}

Annual milk production per cow was similar on both farmlets, averaging $4674 \mathrm{~kg}$ (Table 2). Annual MS production per cow, however, was greater on the No-N

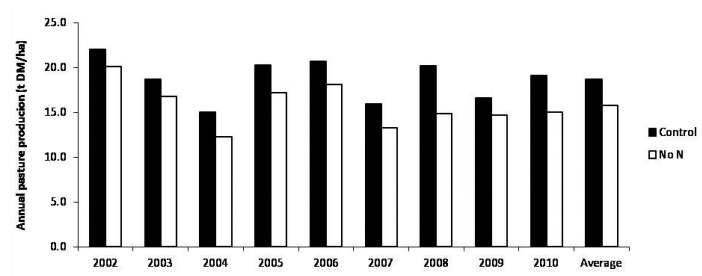

Figure 2. Annual pasture production (t $D M / h a$ ) from the Control and No-N farmlets from 2002 to 2010, and averaged over 2002-2010.

farmlet ( $+21 \mathrm{~kg}, \mathrm{P}<0.01$; Table 2). This was the result of higher fat $(+7 \%$; $\mathrm{P}<0.01)$ and protein yields $(+4 \%$; $\mathrm{P}<0.05$ ).

Interestingly, the difference in milksolids production per cow was not apparent at the start of lactation. In the first 10 weeks of lactation, daily MS yields were similar between the Control and No-N farmlets $(\mathrm{P}>0.05$; Figure 3). There was a tendency for MS yields per cow to be higher in the No-N farmlet in the second 10 weeks of lactation ( $\mathrm{P}=0.08)$; this effect was clearly evident for the remainder of the lactation $(\mathrm{P}<0.05)$. Annual MS per ha were $193 \mathrm{~kg}$ greater $(\mathrm{P}<0.01)$ on the Control farmlet.

\section{Liveweight and BCS}

There were no differences in cow liveweight for early June (late pregnancy) and early December (midlactation, Table 2) between farmlets. The cows on the No-N farmlet were 0.2 BCS units lighter in late June/ early July $(\mathrm{P}<0.05)$ than the control cows, indicating a lower BCS at calving.

\section{Operating Expenses}

Based on 2011-2012 prices, the Control farmlet operating expenses were $\$ 1081 / \mathrm{ha}$ (or $\$ 0.36 / \mathrm{kg}$ MS) greater than the No-N farmlet operating expenses (Table 3).

Table 2. Average annual milk and milksolids yields ( $\mathrm{kg} / \mathrm{cow}$ and $\mathrm{kg} / \mathrm{ha})$, and liveweight and body condition scores of cows from the Control and No-N farmlets.

\begin{tabular}{|c|c|c|c|c|}
\hline & Control & No-N & $\begin{array}{l}\text { Standard } \\
\text { Error }\end{array}$ & $P$ value \\
\hline Lactation length (days) & 263 & 267 & 1.8 & NS \\
\hline \multicolumn{5}{|l|}{ Milk yield } \\
\hline per cow (kg/cow) & 4610 & 4738 & 73.6 & NS \\
\hline \multicolumn{5}{|l|}{ Milksolids yield } \\
\hline per cow (kg/cow) & 371 & 392 & 5.3 & * \\
\hline per hectare $(\mathrm{kg} / \mathrm{ha})$ & 1135 & 942 & 10.8 & ** \\
\hline \multicolumn{5}{|l|}{ Liveweight (kg) } \\
\hline First week in June & 521 & 516 & 7.1 & NS \\
\hline First week in December & 485 & 478 & 7.1 & NS \\
\hline \multicolumn{5}{|l|}{ Body condition score } \\
\hline Late June/early July (before calving) & 4.4 & 4.2 & 0.05 & * \\
\hline
\end{tabular}




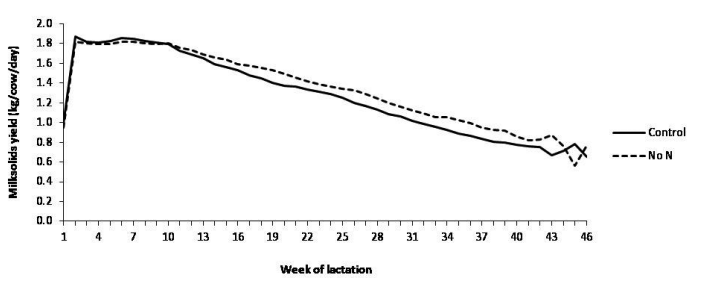

Figure 3. Milksolids yield per cow per day for each week of lactation from the Control and No-N farmlets.

\section{Profitability}

The relative profitability of the farmlets changed with milk price (Table 3 ). Both farmlets were profitable at the lowest milk price experienced during the 9-year period $(\$ 4.60 / \mathrm{kg}$ MS), with the No-N farmlet slightly more profitable at this milk price than the Control farmlet. As milk price increased, the Control farmlet became more profitable than the No-N farmlet. Operating profit/ha for the Control farmlet was $\$ 187 /$ ha higher than the No-N farmlet using the milk price of $\$ 6.07$ and 2011/2012 costs. This increased to $\$ 487 /$ ha with a milk price of $\$ 7.52$. The milk price where profitability was equal for each farmlet has been estimated as $\$ 5.10 / \mathrm{kg}$ MS. Over the life of these farmlets milk price was greater than $\$ 5.10 / \mathrm{kg}$ MS in 3 of the 9 years.

\section{Discussion}

The mean difference between farmlets of $193 \mathrm{~kg}$ $\mathrm{MS} /$ ha/year indicates that the production loss from reducing $\mathrm{N}$ from $180 \mathrm{~kg} \mathrm{~N} / \mathrm{ha}$ annually to zero was $1.07 \mathrm{~kg} \mathrm{MS} / \mathrm{kg} \mathrm{N}$ applied. Milksolids/ha (Table 2) is as measured, with no assumptions made about the MS that might have been produced if replacement heifers were not grazed on the No-N farmlet. Mean herd size (milking cows only) over the life of the farmlets was 21.4 cows (3.06 cows/ha) and 21.6 cows (2.4 cows/ ha) for the Control and No-N farmlets respectively. This provides the basis for the MS/ha comparison in Table 2. The grazing of four replacements on the No-N farmlet increased the herd size to the equivalent of 23 cows (2.56 cow equivalents/ha) and was counted as a cost saving in the profitability calculation (Table
3). In terms of profitability some of the $193 \mathrm{~kg} \mathrm{MS} /$ ha difference was recovered by the partial grazing of replacement heifers on the No-N farm.

The risk to profitability of $\mathrm{N}$ use varied with milk price. The costs of applying $\mathrm{N}$ and then using higher stocking rates to harvest $\mathrm{N}$-boosted grass will exceed the extra revenue when milk price is less than $\$ 5.10 / \mathrm{kg}$ MS. However, milk prices greater than $\$ 6.00 / \mathrm{kg}$ MS have a considerable opportunity cost from not using $\mathrm{N}$ fertiliser applications to increase MS/ha. In only 3 out of 9 years of this study did this occur. Therefore we suggest that "farming within limits" will require farmers (and the industry) to monitor the ratio of milk price to $\mathrm{N}$ fertiliser cost ( $\$ \mathrm{~kg} \mathrm{~N}$ applied). This will help avoid the situation where $\mathrm{N}$ is applied, no additional profit is made and $\mathrm{N}$ leaching limits are threatened. Equally it will allow farmers to readily identify the circumstances when $\mathrm{N}$ applications are profitable and inform the achievement of the balance between profit and $\mathrm{N}$ limits. In late 2013 this ratio has improved to be favourable at 4.2 (milk price $\$ 7.50 / \mathrm{kg} \mathrm{MS}$, applied $\mathrm{N}$ at $\$ 1.80)$. In some years during this comparison the ratio fell to less than 2.5 (milk price less than $\$ 5.50 / \mathrm{kg} \mathrm{MS}$, and $\mathrm{N}$ applied, $\$ 2.20 / \mathrm{kg}$ ). A ratio of this order could generate an alert for low profitability.

The pasture management of the No-N farmlet was similar to the Control farmlet with a focus on maintaining pasture quality through achieving target grazing residuals of $1500 \mathrm{~kg} \mathrm{DM} / \mathrm{ha}$ and harvesting surplus pasture (pre-grazing yields $>3000 \mathrm{~kg} \mathrm{DM} / \mathrm{ha}$ ) as silage. Each farmlet remained self-contained for feed using this approach. After the initial decline in annual pasture yield for the No-N farm, resulting from zero $\mathrm{N}$ applications, there was no obvious trend over time for annual DM yield/ha (Figure 2), indicating that pasture yield had stabilised and soil fertility was maintained by $\mathrm{N}$ fixation by clover when zero $\mathrm{N}$ fertiliser was applied. An important consequence of reduced stocking rate to compensate for reduced pasture production was achieving a similar annual feed allowance per cow $(6.2$ t DM) on each farmlet. This proved to be important for reducing the impact of zero $\mathrm{N}$ fertiliser on $\mathrm{MS}$

Table 3. Mean operating expenses (\$/ha and $\$ / \mathrm{kg} \mathrm{MS)}$ ) and Operating profit (\$/ha) for Control and No-N farmlets calculated using mean milksolids (MS)/ha and a range of low to high milk prices/kg MS.

\begin{tabular}{lccc}
\hline $\begin{array}{l}\text { Operating expenses } \\
\text { (using 2011-2012 prices) }\end{array}$ & Control & No-N & Difference (Control - No-N) \\
\hline \$/ha & 4389 & 3308 & 1081 \\
$\$ / \mathrm{kg}$ MS & 3.87 & 3.51 & 0.36 \\
Operating profit (\$/ha) & & & -91 \\
At milk price \$4.60/kg MS & 1300 & 1391 & +187 \\
At milk price \$6.07/kg MS & 2970 & 2783 & +478 \\
At milk price \$7.52/kg MS & 4617 & 4139 & \\
\hline
\end{tabular}


production, and confirmed the adjustment made to cows/ha through CSR in the planning stage.

Not using nitrogen fertiliser reduces options for filling feed deficits, placing at risk the achievement of critical management targets such as BCS 5 at calving. While the herd on the No-N farmlet had lower BCS at calving, the lower stocking rate and increased daily cow MS production in summer resulted in $21 \mathrm{~kg}$ more MS/cow.

Based on this research, Waikato farmers who have been using up to $200 \mathrm{~kg} \mathrm{~N} / \mathrm{ha}$ per year and are considering a change to a No-N system, should consider the following possible consequences;

- A reduction in annual pasture production/ha (ca. 16\%)

- Increased white clover and weed content in pastures with potential benefits to summer MS yield per cow.

- A reduction in MS production/ha (ca.17\%). This figure could be modified depending on the farm policy for grazing replacement heifers.

- Increased profitability for a no $\mathrm{N}$ policy when milk price is less than $\$ 5.10 / \mathrm{kg}$ milksolids, and decreased profitability when milk price is greater than $\$ 5.10 / \mathrm{kg}$ milksolids.

- Some risk to achievement of critical management targets, such as body condition score at calving.

- The continual need for excellent pasture management.

\section{Conclusion}

Profitable production systems can be achieved without $\mathrm{N}$ fertiliser applications on well-established Waikato dairy pastures. The relative profitability compared with $\mathrm{N}$ fertiliser systems depends on milk price and the costs of applying N. Despite MS production being reduced by $1.07 \mathrm{~kg} \mathrm{MS} / \mathrm{kg} \mathrm{N}$ not applied, profitability was very similar in for these farmlets in 6 out of 9 years.

\section{ACKNOWLEDGEMENTS}

Rodger Jensen ably led this project for the first 6 years. Many other dedicated DairyNZ technicians and farm staff measured and managed these herds over the life of the farmlets. Barbara Kuhn-Sherlock provided statistical analysis.

\section{REFERENCES}

Beukes, P.C.; Scarsbrook, M.R.; Gregorini, P; Romera, A.J ; Clark, D.A.; Catto,W. 2012. The relationship between milk production and farm-gate nitrogen surplus for the Waikato region, New Zealand. Journal of Environmental Management 93: 44-51.
Crush, J.R.; Woodward, S.L.; Eerens, J.P.J; Macdonald, K.A. 2006. Growth and milksolids production in pastures of older and more recent ryegrass and white clover cultivars under grazing. New Zealand Journal of Agricultural Research 49: 119-135.

DairyNZ 2012. Dairy Operating Profit. Farm Facts 9-3. Accessed 12 August 2013 http://www.dairynz. co.nz/page/pageid/2145863981/Dairy_operating_ profit_9-3

DairyNZ 2013. DairyNZ Economic Survey 2011-2012. Accessed 12 August 2013 http://www.dairynz.co.nz/ page/pageid/2145871201/DairyNZ_Economic_ Survey $\# 779$

Ferguson, C.M.; McNeill, M.R.; Phillips, C.B.; Hardwick, S.; Barton D.M.; Kean, J.M. 2012. Status of clover root weevil and its biocontrol agent in the South Island after six years. Proceedings of the New Zealand Grassland Association 74: 171-175.

Glassey, C.B.; Roach, C.G. 2010. Increasing home grown feed on non-irrigated Waikato dairy farms: production, profit and feed use of a demonstration farmlet 2006-2009. pp. 179-184. In: Meeting the challenges for pasture based dairying. Proceedings of the 4th Australasian Dairy Science Symposium. Eds. Edwards, G.R; Bryant, R.H. Christchurch, New Zealand.

Jensen, R.N.; Clark, D.A.; Macdonald, K.A. 2005. Resource efficient dairying trial: measurement criteria for farm systems over a range of resource use. Proceedings of the New Zealand Grassland Association 67: 47-52.

Ledgard, S. F.; Steele, K. W. 1992. Biological nitrogen fixation in mixed legume/grass pastures. Plant and Soil 141: 137-153.

Ledgard, S.F; Sprosen, M.; Judge, A.; Lindsey, S.; Jensen, R.; Clark, D.; Luo, J. 2006. Nitrogen leaching as affected by dairy intensification and mitigation practices in the resource efficient dairying (RED) trial. pp. 263-268. In: Proceedings of the Fertilizer and Lime Research Centre workshop: Implementing sustainable nutrient management strategies in agriculture. Eds. Currie L. D.; Hanly, J. A. Massey University, Palmerston North, New Zealand.

Macdonald, K.A.; Verkerk, G.A.; Thorrold, B.S.; Pryce, J.E.; Penno, J.W; McNaughton, L.R.; Burton, L.J.; Lancaster, J.A.S.; Williamson, J.H.; Holmes, C.W 2008a. A comparison of three strains of HolsteinFriesian grazed on pasture and managed under different feed allowances. Journal of Dairy Science 91: 1693-1707. 
Macdonald, K.A.; Penno, J.W.; Lancaster, J.A.S.; Roche, J.R. 2008b. Effect of stocking rate on pasture production, milk production, and reproduction of dairy cows in pasture-based systems. Journal of Dairy Science 91: 2151-2163.
Ministry for Primary Industries. 2012. Pastoral input trends in New Zealand: a snapshot. p17.

Ministry for the Environment. 2011. National Policy Statement for Freshwater Management. http:// www.mfe.govt.nz/rma/central/nps/freshwatermanagement.html. 
